\title{
PENGARUH GAYA BELAJAR TERHADAP PRESTASI BELAJAR PESERTA DIDIK PADA MATA PELAJARAN PRODUKTIF
}

\author{
Ibnu R. Khoeron ${ }^{1}$, Nana Sumarna ${ }^{2}$, Tatang Permana ${ }^{3}$ \\ Departemen Pendidikan Teknik Mesin \\ Universitas Pendidikan Indonesia \\ Jl. Dr. Setiabudhi No. 207 Bandung 40154 \\ ibnurkhoeron@yahoo.com
}

\begin{abstract}
ABSTRAK
Tujuan penelitian ini untuk memperoleh gambaran tentang gaya belajar dan prestasi belajar peserta didik pada mata pelajaran produktif di SMK Negeri 8 Kota Bandung. Metode yang digunakan adalah metode survei. Hasil penelitian menunjukkan bahwa, sebanyak $35,2 \%$ peserta didik memiliki gaya belajar visual, $55,2 \%$ peserta didik memiliki gaya belajar auditori, dan $29,6 \%$ peserta didik memiliki gaya belajar kinestetik. Secara umum, peserta didik cenderung memiliki gaya belajar visual dan auditori. Hasil pengujian hipotesis menunjukkan bahwa gaya belajar mempunyai hubungan terhadap prestasi belajar. Gaya belajar berpengaruh signifikan terhadap prestasi belajar. Gaya belajar mempunyai kontribusi atau pengaruh sebesar 52\% terhadap prestasi belajar peserta didik dan sisanya $48 \%$ dipengaruhi oleh variabel lain yang tidak di analisis dalam model.
\end{abstract}

Kata kunci: visual, auditori, kinestetik, prestasi, produktif

\section{PENDAHULUAN}

Sekolah Menengah Kejuruan (SMK), merupakan satuan pendidikan yang pada saat ini sedang dikembangkan secara merata oleh pemerintah. Pendidikan kejuruan merupakan pendidikan menengah yang mempersiapkan peserta diklat terutama untuk bekerja dalam bidang tertentu. Banyak permasalahan yang terjadi di SMK, diantaranya ketidakmampuan peserta didik dalam menyerap mata pelajaran yang diberikan oleh pendidik. Metode belajar yang digunakan terlalu monoton dan cenderung sama terhadap seluruh peserta didik. Kemampuan masing-masing peserta didik dalam menyerap dan mengaplikasikan mata pelajaran berbeda-beda. Metode pembelajarannya juga kurang bervariasi yang diterapkan oleh guru, serta belum terciptanya lingkungan atau suasana belajar yang kondusif dan menyenangkan. Keadaan belajar yang sedemikian rupa, membuat para peserta didik merasa kurang nyaman dalam belajar dan memungkinkan hasil belajar yang diharapkan belum dapat tercapai maksimal (Sardiman, 2005).

Pemahaman tenaga pendidik terhadap perbedaan karakteristik yang dimiliki masingmasing peserta didik belum tercapai. Sehingga masih banyak sekali kekurangan selama proses

\footnotetext{
${ }^{1}$ Mahasiswa Departemen Pendidikan Teknik Mesin FPTK UPI

2 Dosen Departemen Pendidikan Teknik Mesin FPTK UPI

${ }^{3}$ Dosen Departemen Pendidikan Teknik Mesin FPTK UPI
} 
pembelajaran, salah satunya berdasarkan faktor internnya, yang didalamnya terdapat perbedaan gaya belajar yang dmiliki oleh masing-masing peserta didik. Gaya belajar merupakan faktor intern yang mempengaruhi prestasi belajar peserta didik. Gaya belajar juga merupakan kunci untuk mengembangkan kinerja dalam pekerjaan, disekolah, dan dalam situasi-situasi antar pribadi (Hamalik, 2003).

Peserta didik pada umumnya memiliki gaya belajar yang berbeda-beda, ada yang gaya belajarnya visual, auditorial, ataupun kinestatik. Kemampuan peserta didik untuk memahami dan menyerap pelajaran pun memiliki tingkatan yang berbeda (Riyanto, 2010). Hanya gaya belajar yang sesuai dengan dirinyalah yang dapat membantu dalam memahami pengetahuan dan menyerap informasi. Namun tidak sedikit peserta didik yang memiliki kesulitan dalam menentukan gaya belajar yang efektif. Pola belajar yang buruk dan tidak teratur, berpotensi menurunkan prestasi belajar sumatifnya. Prestasi yang buruk berpengaruh terhadap kualitas lulusan SMK yang seyogyanya harus memiliki kompetensi mumpuni dalam bidangnya. Hal ini sangat penting, mengingat siswa SMK dipersiapkan sebagai tenaga kerja yang terampil, guna memasuki dunia industri. Tujuan dari penelitian ini untuk memperoleh gambaran tentang gaya belajar dan prestasi belajar peserta didik pada mata pelajaran Produktif di SMK Negeri 8 Kota Bandung dan mengkaji pengaruh gaya belajar terhadap prestasi belajar peserta didik pada mata pelajaran Produktif di SMK Negeri 8 Kota Bandung.

Belajar merupakan suatu proses perubahan yang relatif tetap dalam perilaku individu sebagai hasil dari pengalaman (Winataputra, 2008). Belajar merupakan suatu perubahan dalam kemampuan yang bertahan lama dan bukan berasal dari proses pertumbuhan. Jadi dapat disimpulkan bahwa kegiatan belajar yang dilakukan seseorang mengacu pada perubahan perilaku orang tersebut sebagai hasil dari pengalaman.

Gaya belajar atau learning style merupakan cara peserta didik bereaksi dan menggunakan perangsang-perangsang yang diterimanya dalam proses belajar. Gaya belajar seseorang adalah kombinasi bagaimana ia menyerap, dan kemudian mengatur serta mengolah informasi (DePorter dan Hernacki, 2010). Secara umum gaya belajar dipahami sebagai cara yang disukai oleh peserta didik dalam menyerap, mengolah, mengatur, memahami, mengingat informasi yang diperoleh serta memecahkan permasalahan yang ia hadapi dalam aktivitas belajar dengan berinteraksi dan merespon lingkungan belajarnya.

Banyaknya pendekatan dalam mengklasifikasikan atau membedakan gaya belajar disebabkan karena setiap pendekatan yang digunakan mengakses aspek yang berbeda secara kognitif. Berdasarkan berbagai pendekatan tersebut yang paling terkenal dan sering digunakan 
saat ini ada tiga, yaitu pendekatan berdasarkan preferensi kognitif, profil kecerdasan dan preferensi sensori.

Berdasarkan preferensi sensori atau kemampuan yang dimiliki otak dalam menyerap, mengelola dan menyampaikan informasi, maka gaya belajar individu dapat dibagi dalam tiga kategori. Ketiga kategori tersebut adalah gaya belajar visual, auditorial dan kinestetik yang ditandai dengan ciri-ciri perilaku tertentu.

Gaya belajar visual (visual learners) lebih menitikberatkan pada ketajaman penglihatan. Peserta didik dengan macam gaya belajar seperti ini mengandalkan penglihatan untuk melihat buktinya terlebih dahulu sebelum mereka mempercayainya.

Seseorang dengan gaya belajar visual memiliki ciri-ciri sebagai berikut: rapi dan teratur; berbicara dengan tepat; perencana dan pengatur jangka panjang yang baik; teliti terhadap detail; mementingkan penampilan, baik dalam hal pakaian maupun presentasi; pengeja yang baik dan dapat melihat kata-kata yang sebenarnya dalam pikiran mereka; mengingat apa yang dilihat daripada yang didengarkan; mengingat dengan asosiasi visual; biasanya tidak terganggu oleh keributan; mempunyai masalah untuk mengingat instruksi verbal, kecuali jika ditulis dan sering kali meminta bantuan orang untuk mengulanginya; pembaca cepat dan tekun; lebih suka membaca daripada dibacakan; membutuhkan pandangan dan tujuan yang menyeluruh dan bersikap waspada sebelum secara mental merasa pasti tentang suatu masalah atau proyek; mencorat-coret tanpa arti selama berbicara di telepon dan dalam rapat; lupa menyampaikan pesan verbal kepada orang lain; sering menjawab pertanyaan dengan jawaban singkat ya atau tidak; lebih suka melakukan demonstrasi daripada berpidato; dan lebih suka seni daripada musik.

Upaya mempermudah proses belajar peserta didik dengan gaya belajar visual ini, maka dapat ditempuh beberapa strategi antara lain: menggunakan materi visual, seperti gambar, diagram, dan peta; menggunakan warna untuk meng-hilite hal-hal penting; menggunakan multimedia, seperti komputer dan video; mengajak peserta didik untuk membaca buku-buku berilustrasi; mengajak peserta didik untuk mengilustrasikan ide-idenya ke dalam gambar.

Gaya belajar auditori (auditory learners) mengandalkan pada pendengaran untuk dapat memahami wadan mengingatnya. Karakteristik model belajar seperti ini benar-benar menempatkan pendengaran sebagai alat utama menyerap informasi atau pengetahuan. Artinya, peserta didik harus mendengar, baru kemudian dapat mengingat dan memahami informasi itu. Seseorang dengan gaya belajar auditori memiliki ciri-ciri sebagai berikut: 
berbicara pada diri sendiri saat bekerja; mudah terganggu oleh keributan; menggerakkan bibir mereka dan mengucapkan tulisan di buku ketika membaca; senang membaca dengan keras dan mendengarkannya; dapat mengulangi kembali dan menirukan nada, birama, dan warna suara; merasa kesulitan untuk menulis, tetapi hebat dalam bercerita; berbicara dalam irama yang terpola; biasanya pembicara yang fasih; lebih suka musik daripada seni; belajar dengan mendengarkan dan mengingat apa yang didiskusikan daripada yang dilihat; suka berbicara, berdiskusi, dan menjelaskan sesuatu panjang lebar; mempunyai masalah dengan pekerjaanpekerjaan yang melibatkan visualisasi, seperti memotong bagian-bagian hingga sesuai satu sama lain; lebih pandai mengeja dengan keras daripada menuliskannya; dan lebih suka gurauan lisan daripada membaca komik.

Adapun strategi yang dapat ditempuh oleh pendidik/orang tua guna mempermudah proses belajar peserta didik/anak dengan gaya belajar auditori, antara lain: mengajak peserta didik/anak untuk ikut berpartisipasi dalam diskusi, baik di dalam kelas maupun di dalam keluarga; mendorong peserta didik/anak untuk membaca materi pelajaran dengan keras; pada saat belajar, sebaiknya disertai dengan alunan musik; mendiskusikan ide-ide dengan peserta didik/anak secara verbal; dan membiarkan peserta didik/anak merekam materi pelajarannya ke dalam kaset dan mendorongnya untuk mendengarkan rekaman tersebut sebelum tidur.

Gaya belajar kinestetik (kinesthetic learners) mengharuskan individu yang bersangkutan menyentuh sesuatu yang memberikan informasi tertentu agar peserta didik dapat mengingatnya. Ciri-ciri gaya belajar kinestetik sebagai berikut: berbicara dengan pelan; menanggapi perhatian fisik; menyentuh orang untuk mendapatkan perhatian mereka; berdiri dekat ketika berbicara dengan orang; selalu berorientasi pada fisik dan banyak bergerak; mempunyai perkembangan awal otot-otot yang besar; belajar melalui memanipulasi dan praktik; menghapal dengan cara berjalan dan melihat; menggunakan jari sebagai alat penunjuk ketika membaca; banyak menggunakan isyarat tubuh; dan tidak dapat duduk diam untuk waktu lama.

Adapun beberapa strategi yang dapat ditempuh oleh pendidik dan orang tua guna mempermudah peserta didik/anak dalam proses belajarnya, antara lain: tidak boleh terlalu memaksakan peserta didik/anak untuk belajar sampai berjam-jam; mengajak peserta didik/anak untuk belajar sambil mengeksplorasi lingkungannya, misalnya menggunakan objek sesungguhnya untuk belajar konsep baru; memberikan izin kepada peserta didik/anak untuk mengunyah permen karet pada saat belajar; memberikan izin kepada peserta didik/anak untuk 
belajar sambil mendengarkan musik; dan menggunakan warna terang untuk meng-hilite halhal penting dalam bacaan.

Prestasi belajar merupakan indikator kualitas dan kuantitas pengetahuan yang telah dikuasai siswa adalah umpan balik bagi guru dalam melaksanakan proses belajar mengajar. Prestasi belajar adalah hasil yang diperoleh seseorang selama proses pembelajaran, usaha untuk belajar, pemahaman pengetahuan, pengaplikasian keterampilan dalam suatu mata pelajaran yang diujikan melalui tes. Terdapat 9 faktor yang dapat mempengaruhi prestasi belajar peserta didik, yaitu: peserta didik, guru, tujuan belajar, materi pelajaran, sarana belajar, interaksi peserta didik dengan materi pelajaran, interaksi guru dengan peserta didik, interaksi antar peserta didik, dan lingkungan mengajar.

\section{METODE PENELITIAN}

Metode penelitian yang digunakan adalah metode survei. Survei dilakukan pada peserta didik Kelas XI TKR SMK Negeri 8 Kota Bandung dengan jumlah 71 orang. Penentuan sampel metode simple random sampling. Pengambilan data penelitian diambil dengan menggunakan tes dan dokumentasi.

\section{HASIL PENELITIAN}

Survei telah dilakukan kepada semua responden di SMKN 8 Kota Bandung. Hasil peneliti terhadap gaya belajar peserta didik telah diringkas pada Tabel. 1.

Tabel 1. Gaya belajar peserta didik

\begin{tabular}{ccc}
\hline Gaya Belajar & Frekuensi & Persentase (\%) \\
\hline Visual & 25 & 35,2 \\
Auditori & 25 & 35,2 \\
Kinestetik & 21 & 29,6 \\
Jumlah & 71 & 100 \\
\hline
\end{tabular}

\section{PEMBAHASAN}

Hasil penelitian menunjukkan bahwa peserta didik kelas XI TKR SMK Negeri 8 Kota Bandung sebanyak 25 peserta didik $(35,2 \%)$ memiliki gaya belajar visual, 25 peserta didik $(35,2 \%)$ memiliki gaya belajar auditori, dan 21 peserta didik $(29,6 \%)$ memiliki gaya belajar 
kinestetik. Ini berarti bahwa peserta didik kelas XI TKR SMK Negeri 8 Kota Bandung cenderung memiliki gaya belajar visual dan auditori.

Dominannya gaya belajar visual dan auditori ditunjukkan dengan banyaknya peserta didik yang saat mendapat tugas dari guru, biasanya akan melihat teman-teman lainnya dahulu, baru kemudian bertindak sendiri, serta senang berdiskusi dan berkomunikasi dengan orang lain saat belajar di kelas.

Pada dasarnya, ketiga gaya belajar dimiliki oleh peserta didik, namun peserta didik tersebut memiliki kecenderungan pada salah satu gaya belajar, bahkan tidak menutup kemungkinan peserta didik mengkombinasikan gaya belajar tersebut guna menunjang proses belajarnya (Djamarah dan Zain, 2006). Berdasarkan itu, semakin sesuai gaya belajar dengan kepribadian peserta didik, maka akan semakin tinggi prestasi akademik peserta didik tersebut guna mencapai prestasi belajar. Sebaliknya, semakin tidak sesuai gaya belajar dengan kepribadian peserta didik, maka akan semakin rendah prestasi akademiknya. Dengan begitu baik disadari maupun tidak, gaya belajar merupakan salah satu kunci untuk mengembangkan kinerja dalam kegiatan belajar sehingga belajar peserta didik dapat dikatakan efektif.

Jumlah keseluruhan kelas XI TKR SMK Negeri 8 Kota Bandung sebanyak 247 peserta didik dan yang dijadikan sampel pada penelitian ini adalah sebanyak 71 peserta didik. Masing-masing tiap sampel peserta didik, memiliki gaya belajar yang khas, baik itu gaya belajar visual $(35,2 \%)$, auditori $(35,2 \%)$, dan kinestetik $(29,6 \%)$. Berdasarkan hal tersebut peserta didik kelas XI TKR SMK Negeri 8 Kota Bandung sebesar 70,4\% cenderung memiliki gaya belajar visual dan auditori. Prestasi belajar peserta didik kelas XI TKR SMK Negeri 8 Kota Bandung yang tercermin oleh hasil belajar, berada dalam kategori tinggi. Hal ini ditunjukkan dengan banyaknya peserta didik yang memperoleh nilai di atas nilai KKM.

Gaya belajar sebagai salah satu faktor dalam diri peserta didik berpengaruh sebesar $52 \%$ yang merupakan pengaruh tinggi terhadap pencapaian prestasi belajar peserta didik kelas XI TKR SMK Negeri 8 Kota Bandung. Artinya, bahwa semakin sesuai gaya belajar dengan kepribadian peserta didik, maka akan semakin tinggi prestasi akademik peserta didik tersebut guna mencapai prestasi belajar. Berbanding terbalik apabila semakin tidak sesuai gaya belajar dengan kepribadian peserta didik, maka akan semakin rendah prestasi akademiknya. 


\section{KESIMPULAN}

Kesimpulan penelitian ini yaitu peserta didik cenderung memiliki gaya belajar visual dan auditori. Hasil penelitian menunjukkan bahwa, 35,2\% peserta didik memiliki gaya belajar visual, $55,2 \%$ peserta didik memiliki gaya belajar auditori, dan $29,6 \%$ peserta didik memiliki gaya belajar kinestetik. Gaya belajar mempunyai hubungan terhadap dan berpengaruh signifikan terhadap prestasi belajar. Gaya belajar mempunyai kontribusi atau pengaruh sebesar 52\% terhadap prestasi belajar peserta didik.

\section{DAFTAR PUSTAKA}

DePorter, B dan Hernacki, M. (2010). Quantum Learning: Membiasakan Belajar Nyaman dan Menyenangkan. Bandung: Kaifa.

Djamarah, S dan Zain, A. (2006). Strategi Belajar Mengajar. Jakarta: Rineka Cipta.

Riyanto, Y (2010). Paradigma Baru Pembelajaran. Jakarta: Prenada Media Grup

Winataputra, U. S. (2008). Teori Belajar dan Pembelajaran. Jakarta: Universitas Terbuka.

Sardiman. (2005). Interaksi dan Motivasi Belajar Mengajar. Jakarta: Rajawali Pers.

Hamalik, O. (2003). Proses Belajar Mengajar. Jakarta: Bumi Aksara. 